DOI https://doi.org/10.18551/rjoas.2020-09.03

\title{
THE GROWTH, PRODUCTION OF SORGHUM (SORGHUM BICOLOR [L.] MOENCH) AND CHANGES IN CHEMICAL SOIL PROPERTIES DUE TO THE TREATMENT OF MULCH AND ORGANIC FERTILIZER
}

\author{
Irmansyah T. ${ }^{1 *}$, Rauf Abdul ${ }^{2}$, Delvian $^{3}$, Akoeb Erwin Nyak ${ }^{2}$ \\ ${ }^{1}$ Doctoral Program in Agricultural Science, Universitas Sumatera Utara, Medan, Indonesia \\ ${ }^{2}$ Agricultural Science, Universitas Sumatera Utara, Medan, Indonesia \\ ${ }^{3}$ Faculty of Forestry, Universitas Sumatera Utara, Medan, Indonesia
}

*E-mail: t.irmansyah@usu.ac.id

\begin{abstract}
Sorghum is a commodity which is expected to be an alternative food source to reduce the need for national rice. This plant has great potential to be developed in Indonesia because it has a large area of adaptation, including on degraded dry land. This study aims to analyse the growth and production of sorghum plants and changes in chemical soil properties due to the treatment of mulch and organic fertilizer in the first planting period. The study design uses a Split Plot Design, which the Main-Plots is mulching, consist of M0: None mulch, and M1: Straw mulch; Sub-Plot (organic fertilizer) consisting of: B0: None organic fertilizer (0 ton ha-1), B1: Cow manure (25 ton ha-1), B2: Compost (25 ton ha-1), B3: Cow manure (12.5 tons ha-1) + compost (12.5 tons ha-1). This study finding that organic fertilizer significantly increased vegetative and yield of sorghum. In addition, cultivating sorghum either without mulching or by applying mulch and organic fertilizers can improve soil chemical properties in dry land.
\end{abstract}

\section{KEY WORDS}

Sorghum, yield, manure, mulch, degraded land.

Food needs will continue to increase along with the increase in the world's population, including in Indonesia. At present the population of Indonesia reaches more than 260 million, which is a big challenge to meet national food needs, both in the normal and abnormal conditions, including global pandemic conditions such as Covid-19. Dependence on food needs from rice has a high vulnerability due to various policy and technical issues within. Ones the potential alternative foodstuff as a substitute for rice is sorghum (Sorghum bicolor [L.] Moench). Sorghum has a calorie content that is almost equivalent to rice and corn, with a higher protein content than rice. Therefore, in Indonesia sorghum is one of the commodities that can be expected to be an alternative food source to reduce national rice needs.

Sorghum is one kind of cereal plant that has great potential to be developed in Indonesia because it has a large area of adaptation. Sorghum plants are tolerant to drought and stagnant water, can produce on marginal land, and are relatively resistant to pest / disease disorders.

The area of critical land in Aceh Province in 2001 reached 1,823,533 hectares (Mahyuddin et.al, 2013), an increase compared to the area of critical land in 2002 which was $860,659.93$ ha, with details: very critical 5,777 ha, critical $320,248.13$ ha, rather critical 96,738.29 ha, and critical potential of 437,896.51 ha (Bukhari and Febryano, 2010). Whereas, in Aceh Besar District, the area of critical land reaches 31,319 ha consisting of critical land inside the forest area of 7,819 ha, rather critical 1,059 ha and outside the forest area of critical land 17,921 ha and rather critical 4,520 ha (BPS, 2019). Irmansyah et al. (2020) noted that there are 4,229 ha of critical land in Blang Bintang Sub-district and 3,135 ha in Indrapuri Sub-district, which generally very low - low soil fertility status.

Most dry land soils have low soil fertility and organic matter content. Without the addition of organic matter that has complete nutrient content, soil fertility and productivity are difficult to increase. Some of the benefits of providing organic matter are increasing soil 
humus content, reducing environmental pollution, reducing nutrient transport in the form of harvests and erosion, improving soil properties and soil health (Prihastanti, 2010). But the supply of organic ingredients must still pay attention to the efficiency of their use. It should be known that the optimum dose of fertilizer should be given to sorghum plants, while there are still very few sources of literature that provide the best dose of manure for sorghum plants. According to Datta et al. (2018), providing a balanced dose of organic fertilizers not only gives higher yields but also increases soil organic $\mathrm{C}$ reserves under hot semi-arid conditions, even in intensive cultivation.

Based on previous research states that the provision of organic material can increase the growth and yield of sorghum, especially the weight component of seeds (Pramanda et.al, 2015). Irawan et.al (2020) also reported that the application of buffalo manure had a significant effect on the parameters of observing flowering age, harvest age and dry weight of seeds. Fertilization from cow dung was also reported to increase the production of sorghum plants as measured by panicle length, panicle weight and seed weight (Tacoh et.al, 2017). Improvement of sorghum cultivation through fertilization has been done a lot, but there have been no reports related to the use of mulch in sorghum cultivation. This needs to be considered because sorghum cultivation is mostly done on dry land which has environmental limiting factors such as water availability and high air temperatures. This study aims to analyse the growth and production of sorghum plants and changes in chemical soil properties due to the treatment of mulch and organic fertilizer in the first planting period in Indrapuri Sub-District, Aceh Besar Regency.

\section{METHODS OF RESEARCH}

The study design uses a Split Plot Design, which the Main-Plots is mulching, consist of M0: None mulch, and M1: Straw mulch; Sub-Plot (organic fertilizer) consisting of: B0: None organic fertilizer (0 ton ha-1), B1: Cow manure (25 ton ha-1), B2: Compost (25 ton ha-1), B3: Cow manure (12.5 tons ha- 1$)+$ compost (12.5 tons ha- 1$)$. The experiment was replicated 3 times to obtain 24 units of the experimental plot. The plot size is $1.5 \times 3$ meters with spacing of $20 \mathrm{~cm} \times 70 \mathrm{~cm}$ so that there are 40 plants per plot. Plant samples from each plot of 18 plants, each planting hole grown by one plant.

Plant parameters observed included:

1) Stem Diamater. Stem diameter measurements were taken at the end of the vegetative period (9 weeks after planting). Stem diameter measurement using Calipers, the plant whose stem diameter is measured is the sample plant, which is measured at the base of the plant stem 4 times on different sides

2) Yield per plot. Plot production data obtained from weighing the plot seeds. The weighed seeds are first removed from panicles and the seeds are dried in the sun to a moisture content of $12-14 \%$, and then cleaned by sifting / winnowing the sorghum seeds so that they are free from various impurities.

3) 1000 seeds weight. Data on the weight of 1000 seeds was obtained from weighing 1000 sorghum seeds which had a moisture content of $12-14 \%$.

At the end of the planting period, soil samples from each plot were analyzed at the Deli Tobacco Research Centre (BPTD) PTPN II Sampali-Medan, covering: C-organic, N-total, soil $\mathrm{pH}(\mathrm{H} 2 \mathrm{O}), \mathrm{P} 2 \mathrm{O} 5, \mathrm{~K}$ exchange and CEC (Table 1).

Land Preparation. The planting area was preparation with a hand tractor and continued with a hoe, then made 3 experimental plots with the size of each plot are $4.5 \mathrm{~m} \times 14.5 \mathrm{~m}$ (main plot), each main plot is divided into 8 sub-plots measured $1.5 \mathrm{mx} 3 \mathrm{~m}$, distance between plots $0.5 \mathrm{~m}$ and the distance between treatment is $1 \mathrm{~m}$ which extends from north to south.

Planting. Before sorghum are planted, first make a planting hole using a tool as deep as $3 \mathrm{~cm}$, and placed 3 seeds of sorghum in planting hole (after 1 week old plants, do the chopping, leaving 1 plant by pulling other plants). Before planting, sorghum seeds soak them in water for 10 minutes, which is intended to help accelerate the germination process. Planting spacing used is $20 \times 70 \mathrm{~cm}$. 
Table 1 - Parameters and methods of soil chemical properties analysis

\begin{tabular}{|l|l|l|}
\hline NO & SOIL CHEMICAL PROPERTIES & METHOD OF ANALYSIS \\
\hline 1 & PH & PH METER (ELECTROMETRIC) \\
\hline 2 & C-ORGANIK & WALKLEY AND BLACK \\
\hline 3 & N-TOTAL & KJELDAHL \\
\hline 4 & P2O5 & EXTRACTION HCL 25\% \\
\hline 5 & K_DD & EXTRACTION HCL 25\% \\
\hline 6 & CATIONS EXCHANGE CAPACITY & EXTRACTION 1N NH4COOCH3PH 7 \\
\hline
\end{tabular}

Mulch application. Rice straw used as mulch is rice straw taken from the area of newly harvested community rice fields (fresh rice straw), and without being chopped. Rice straw apply by laying on the ground surface of the experimental plot (according to the experimental design) evenly, as for rice straw that is used as mulch in this study was as much as 10 tons ha-1. Mulching application in the experimental plot is done when the plant is 1 week old.

Organic Fertilizer Application. Application of organic fertilizer is carried out after the soil treatment is complete. Dose according to the experimental design by sprinkling on the surface of the soil and then reversing using a hoe, this step is done so that organic fertilizer can be distributed evenly.

\section{RESULTS AND DISCUSSION}

Stem diameter of sorghum plant $(\mathrm{mm})$. Results of analysis of variance showed that the treatment of organic fertilizer had a significant effect, whereas the treatment of mulch and the combination of mulch with organic fertilizer did not have a significant effect (Table 2).

Table 2 - Effect of mulch and organic fertilizer on stem diameter $(\mathrm{mm})$

\begin{tabular}{|c|c|c|c|c|c|}
\hline Treatment & B0 & B1 & B2 & B3 & Average \\
\hline M0 & 24.51 & 27.52 & 23.86 & 33.02 & $27.23^{\mathrm{a}}$ \\
\hline M1 & 22.96 & 30.86 & 29.43 & 31.18 & $28.61^{\mathrm{a}}$ \\
\hline Average & $23.74^{\mathrm{b}}$ & $29.19^{\mathrm{a}}$ & $26.65^{\mathrm{ab}}$ & $32.10^{\mathrm{a}}$ & \\
\hline
\end{tabular}

Note: The numbers with marked by different letters on the same row and column show significant based on Duncan's multiple range test at $5 \%$ level.

Table 2 shows that there is no significant difference in stem diameter between mulch treatments, but a real difference occurs between the treatment of cow manure (B1) and the mixture of cow manure + compost (B3) with treatment without organic fertilizer. The highest stem diameter is found in the treatment of cow manure + compost (B3), which is $32.10 \mathrm{~mm}$, an increase of $35.21 \%$ when compared to the treatment without organic fertilizer. While the combination of treatment without mulch with cow manure + compost (M0B3) treatment is the treatment that gives the highest diameter or stem diameter increased by $34.72 \%$ when compared to the combination of treatment without mulch without organic fertilizer (M0B0). Increasing the diameter of the stem in the treatment of cow manure is suspected that cow manure can maintain the environmental conditions needed by sorghum plants. Cow manure and mulch can increase water availability, reduce extreme temperature fluctuations, so that life and activity of soil microorganisms, such as mycorrhizal fungi, increase. Mycorrhizae are known to interact synergistically with phosphate solvent bakers or N. binding bacteria.

Sorghum production per plot $(\mathrm{kg})$. The results of analysis of variance on sorghum crop production parameters showed that the treatment of organic fertilizer had a significant effect, whereas the treatment of mulch and the combination of mulch with organic fertilizer did not have a significant effect (Table 3).

In Table 3 it can be seen that based on Duncan's test, compost (B2) treatment was significantly different from the treatment of a mixture of cow manure with compost (B3). Treatment of cow manure (B1) and compost (B2) is significantly different from treatment without organic matter (B0) and treatment of cow manure + compost (B3). The highest production of sorghum plants per plot was in treatment B2 (compost) with a value of $4.25 \mathrm{~kg}$ and the lowest was in B0 (without organic fertilizer) with a value of $2.79 \mathrm{~kg}$, so there was an 
increase in production of sorghum plants per plot valued at $52.33 \%$. This is because compost is an organic fertilizer that can affect the physical properties of the soil, making the soil loose, so that aeration is better and more easily penetrated by plant roots, regulating soil moisture, facilitating the entry of water into the soil and then storing water, which is this condition making the soil a good place to store water and as a source of micro nutrients, growth regulators needed by plants (Erwin, 2007). Syahidah et al. (2002), added that the nutrient $P$ functions to accelerate flowering, ripening fruit / seeds / grain and can increase production.

Table 3 - Effects of mulch and organic fertilizer on sorghum crop production per plot $(\mathrm{kg})$

\begin{tabular}{|c|c|c|c|c|c|}
\hline Treatment & B0 & B1 & B2 & B3 & Average \\
\hline M0 & 2.49 & 3.96 & 4.39 & 3.10 & $3.49^{\mathrm{a}}$ \\
\hline M1 & 3.09 & 4.25 & 4.11 & 2.53 & $3.50^{\mathrm{a}}$ \\
\hline Average & $2.79^{\mathrm{b}}$ & $4.11^{\mathrm{a}}$ & $4.25^{\mathrm{a}}$ & $2.81^{\mathrm{b}}$ & - \\
\hline
\end{tabular}

Note: The numbers with marked by different letters on the same row and column show significant based on Duncan's multiple range test at 5\% level.

Weight of 1000 seeds of sorghum plant $(\mathrm{g})$. Results of analysis of variance on the weight parameters of 1000 seeds showed that the treatment of organic fertilizer had a significant effect, whereas the treatment of mulch and the combination of mulch with organic fertilizer did not have a significant effect (Table 4).

Table 4 - Effect of mulch and organic fertilizer on the weight of 1000 seeds $(\mathrm{g})$

\begin{tabular}{|c|c|c|c|c|c|}
\hline Treatment & B0 & B1 & B2 & B3 & Average \\
\hline M0 & 27.83 & 45.75 & 39.87 & 42.36 & $38.96^{\mathrm{a}}$ \\
\hline M1 & 33.62 & 44.97 & 42.11 & 39.33 & $40.01^{\mathrm{a}}$ \\
\hline Average & $30.73^{\mathrm{C}}$ & $45.36^{\mathrm{a}}$ & $40.99^{\mathrm{b}}$ & $40.85^{\mathrm{b}}$ & - \\
\hline
\end{tabular}

Note: The numbers with marked by different letters on the same row and column show significant based on Duncan's multiple range test at 5\% level.

Based on Duncan's test it can be seen that the treatment of cow manure (B1) gives the highest value in the parameter of 1000 seeds and, which is worth $45.36 \mathrm{~g}$, is significantly different from the treatment of compost (B2) and a mixture of cow manure with compost (B3). The treatment of cow manure (B1) is also significantly different from the treatment without organic fertilizer (B0). The treatment of cow manure (B1) can increase the weight of 1000 seeds worth $47.61 \%$ when compared to B0 (without organic fertilizer. Statistically mulch treatment does not contribute to weight of 1000 seeds, but can increase the weight of 1000 sorghum seeds by $2.7 \%$. The results of this study are in line with the findings of Wang et al (2017) which states that the source of $P$ fertilizer has an effect on the yield components of sorghum.

It is suspected that to carry out physiological processes in the formation of plant seeds requires appropriate and balanced nutrients, cow manure also plays a role in helping to improve soil structure so that soil aggregates are more stable and can also help the availability of nutrients, especially micro nutrients. Tamba (2016) says that cow manure can increase nutrient availability and also helps increase plant growth and production. Then Melati and Andriyani (2005) also said that cow manure has high fiber, such as cellulose. Cow manure can produce and improve soil porosity, increase the composition of microorganisms in the soil, provide macro and micro nutrients for plants and facilitate root growth. The results of Manonggotua (2015) concluded that the sorghum variety of Numbu gave a weight of 1000 seeds, the highest production per sample and production per plot compared to Kawali varieties.

C-organic soil (\%). Based on the results of analysis of variance on the parameters of soil C-organic content, it shows that organic fertilizer has a real effect, whereas the treatment of mulch and the combination of mulch and organic fertilizer has no real effect.

Table 5 shows that Duncan's distance test results state that cow manure (B1) is not significantly different in terms of C-organic content when compared with compost (B2) 
treatment and a mixture of cow manure with compost (B3), however all organic fertilizer treatments (B1, B2, B3) are significantly different from the treatment without organic fertilizer (B0). It can be seen that mulch treatment has soil C-organic content of $2.40 \%$, whereas without mulch, soil C-organic content is $2.21 \%$ and this does not show any significant difference between mulch treatment and without mulch treatment of $\mathrm{C}$ - organic. However, straw mulch applied to sorghum cultivation in dry land can increase soil C-organic content by $8.60 \%$.

Table 5 - Effect of mulch and organic matter on C-organic content (\%)

\begin{tabular}{|c|c|c|c|c|c|}
\hline Treatment & B0 & B1 & B2 & B3 & Average \\
\hline M0 & 1.53 & 2.57 & 2.54 & 2.22 & 2.21 \\
\hline M1 & 1.40 & 2.81 & 2.81 & 2.60 & 2.40 \\
\hline Average & $1.46^{\mathrm{b}}$ & $2.69^{\mathrm{a}}$ & $2.68^{\mathrm{a}}$ & $2.41^{\mathrm{a}}$ & - \\
\hline
\end{tabular}

Note: The numbers with marked by different letters on the same row and column show significant based on Duncan's multiple range test at 5\% level.

The highest organic fertilizer treatment without mulch at B1 (manure) treatment was $2.57 \%$ and the lowest was at B0 (without organic fertilizer) at $1.53 \%$, this condition showed that cow manure without mulch treatment (M0B1), could increase the level of C- soil organic matter worth $67.97 \%$ when compared to the treatment without mulch and without organic matter (M0B0) Whereas the organic fertilizer treatment with the highest mulch at B1 (cow manure) and B2 (compost) is $2.81 \%$ and the lowest is at B0 (without organic fertilizer ) which is $1.40 \%$. Nasution et al., (2015) concluded that the addition of manure significantly affected the soil C-Organic content, this is because organic matter (manure) in the soil would be decomposed by soil microorganisms that use it as a source of food and energy into humus, so with the amount of organic matter supplied, the higher the C-Organic value of the soil (Sandrawati, 2007)

The condition of $\mathrm{MOB0}$ is without mulch treatment and without organic matter treatment, giving a value of $1.53 \%$, meaning that sorghum plants can increase soil C-organic by $70 \%$ from the initial soil condition (K0) where the C-organic content is $0.90 \%$, very low. The results of observations of $\mathrm{C}$-organic levels indicate that sorghum plants can improve soil fertility, because it can increase soil C-organic. The ability of sorghum plants to increase the C-organic soil is thought to be due to the exudate process of organic acids in the rooting region or rhizosphere. According to Marschner (2012) external efficiency can be improved through better root development or by increasing exudation of organic acids.

$N$-total (\%). In Table 6 it can be seen that based on Duncan's test, there were no real differences between the treatments of organic fertilizer for total $\mathrm{N}$-soil. In the parameters of the highest soil $\mathrm{N}$-Total levels were in treatment $\mathrm{B} 2$ (compost) with a value of $0.37 \%$ and the lowest were in B0 (without organic matter) with a value of $0.23 \%$, an increase in $\mathrm{N}$-total soil was worth $60.87 \%$, whereas cow manure (B1) and compost + cow manure (B3) can each increase $\mathrm{N}$-total soil by $39.13 \%$, when compared to treatments without organic fertilizer.

Table 6 - Effect of mulch and organic matter on $\mathrm{N}$-total content in sorghum cultivation (\%)

\begin{tabular}{|c|c|c|c|c|c|}
\hline Treatment & B0 & B1 & B2 & B3 & Average \\
\hline M0 & 0.22 & 0.32 & 0.41 & 0.28 & 0.31 \\
\hline M1 & 0.23 & 0.32 & 0.32 & 0.37 & 0.31 \\
\hline Average & $0.23^{\mathrm{ab}}$ & $0.32^{\mathrm{a}}$ & $0.37^{\mathrm{a}}$ & $0.32^{\mathrm{a}}$ & \\
\hline
\end{tabular}

Note: The numbers with marked by different letters on the same row and column show significant based on Duncan's multiple range test at $5 \%$ level.

The highest $\mathrm{N}$-total value in the combination of treatments without mulch and compost fertilizer was $0.41 \%$ (MOB2) and the lowest at MOB0 was $0.22 \%$, this shows that the combination of treatments without mulch and compost increased $\mathrm{N}$-total by $86.36 \%$. While mulch treatment has not increased the total $\mathrm{N}$-soil. It can be suspected that compost as an organic fertilizer can supply $\mathrm{N}$ to the soil. Erwin (2007) states that organic fertilizers are slow 
release fertilizers, meaning that the nutrients in the fertilizer are released slowly and continuously in a certain period of time so that the loss of nutrients due to washing by water is smaller. Nutrient release of organic fertilizer is slower than chemical fertilizer. Nutrients contained in organic fertilizer there is money available directly and indirectly. The elements that are not available with the help of micro-organisms in the soil will be converted into forms that can be taken by plants. Organic nitrogen in the soil will change to the forms available to plants. Organic nitrogen is converted into ammonium compounds by ammonification bacteria, then ammonium compounds are converted to nitrates by nitrification bacteria. Plants absorb nitrogen in the form of nitrate (as a result of changes in organic nitrogen by micro-organisms. Hanafiah et al, (2009) which states that in addition to water, carbon and energy, nitrogen is also an essential element for all living things. Nitrogen is referred to as a key element of production, and very often becomes a limiting factor for plant growth and crop production in soil ecosystems. Nitrogen is needed by plants in large quantities.

$\mathrm{pH}$ (H2O). Results of analysis of variance showed that organic fertilizer, mulch and the combination of mulch with organic matter did not have a significant effect on changes in $\mathrm{pH}$ (H2O) (Table 7).

Table 7 - Effect of mulch and organic matter on soil pH (H2O) in sorghum cultivation

\begin{tabular}{|c|c|c|c|c|c|}
\hline Treatment & B0 & B1 & B2 & B3 & Average \\
\hline M0 & 6.10 & 6.30 & 6.30 & 6.33 & 6.26 \\
\hline M1 & 6.43 & 6.37 & 6.47 & 6.47 & 6.44 \\
\hline Average & 6.27 & 6.34 & 6.39 & 6.40 & - \\
\hline
\end{tabular}

Note: The numbers with marked by different letters on the same row and column show significant based on Duncan's multiple range test at $5 \%$ level.

Sorghum cultivation can change soil $\mathrm{pH}$. In the treatment without mulch the highest treatment in B3 (sorghum plants, manure and compost) is 6.33 and the lowest is in B0 (sorghum plants, without organic fertilizer) which is 6.10. Whereas the highest mulch treatment in B2 (compost) and B3 (, manure and compost) is 6.47 and the lowest is in B1 (sorghum plants, and manure) which is 6.37. The condition of MOB0 is sorghum plants without mulch treatment and without organic matter treatment, giving a value of 6.10 means that sorghum plants reduce the $\mathrm{pH}$ value $(\mathrm{H} 2 \mathrm{O})$ of the soil by $18.52 \%$ from the condition of the natural / initial soil (KO) where the soil pH level is 7.23.

P2O5 (ppm). The treatment of organic fertilizer had a significant effect, whereas the treatment of mulch and the combination of mulch with organic fertilizer did not have a significant effect. In Table 8 it can be seen that the highest P2O5 treatment is in the B3 treatment (cow manure + compost fertilizer) with a value of $18.10 \mathrm{ppm}$ and the lowest is in B0 (without organic matter) with a value of $8.46 \mathrm{ppm}$,

Table 8 - Effects of sorghum, mulch and organic matter cultivation on soil $\mathrm{P}_{2} \mathrm{O}_{5}(\mathrm{ppm})$

\begin{tabular}{|c|c|c|c|c|c|}
\hline Treatment & B0 & B1 & B2 & B3 & Average \\
\hline M0 & $7.45(\mathrm{SR})$ & $8.86(\mathrm{R})$ & $14.53(\mathrm{R})$ & $18.50(\mathrm{~S})$ & 12.33 \\
\hline M1 & $9.47(\mathrm{R})$ & $13.62(\mathrm{R})$ & $17.23(\mathrm{~S})$ & $17.70(\mathrm{~S})$ & 14.51 \\
\hline Average & $8.46 \mathrm{~d}$ & $11.24 \mathrm{c}$ & $15.88 \mathrm{~b}$ & $18.10 \mathrm{a}$ & - \\
\hline
\end{tabular}

Note: The numbers with marked by different letters on the same row and column show significant based on Duncan's multiple range test at $5 \%$ level.

In Table 8 it can also be seen that based on Duncan's test, the treatment mix of cow manure with compost (B3) is significantly different from the treatment of cow manure (B1) and compost (B2). All treatments of organic fertilizer were significantly different from treatments without organic fertilizer. In the treatment without mulch, the highest P2O5 in the B3 treatment (sorghum plants, manure and compost) was $18.50 \mathrm{ppm}$ and the lowest was in B0 (sorghum plants, without organic fertilizer) which was $7.45 \mathrm{ppm}$. Whereas in the treatment with P2O5 mulch the highest in B3 (sorghum plants, manure and compost) was 17.70 ppm and the lowest was in B0 (sorghum plants, without organic fertilizer) which was $9.47 \mathrm{ppm}$. It 
is suspected that the treatment of cow manure and compost (B3) fertilizer which is the best organic fertilizer in phosphate increase compared to cow manure and compost given singly, due to the presence of organic acids resulting from the decomposition of organic matter capable of dissolving $\mathrm{P}$ and elements another of its binders, results in increased availability and efficiency of $P$ fertilization and other nutrients. Nagur (2017) adds that the negative correlation $P$ value in organic soil soils does not indicate the role of $P$ nutrients such as assisting in photosynthesis, respiration, transfer and storage of energy division and cell enlargement and processes in other plants.

K-exchange (me / 100g). In the exchanged $\mathrm{K}$ parameter, the treatment of organic fertilizer had a significant effect, whereas the treatment of mulch and the combination of mulch and organic matter had no significant effect (Table 9).

Table 9 - Effects of sorghum, mulch and organic matter cultivation on soil K-exchange (me/ $100 \mathrm{~g}$ )

\begin{tabular}{|c|c|c|c|c|c|}
\hline Treatment & B0 & B1 & B2 & B3 & Average \\
\hline M0 & $0.57(\mathrm{~S})$ & $0.73(\mathrm{~T})$ & $1.49(\mathrm{ST})$ & $0.79(\mathrm{~T})$ & 0.90 \\
\hline M1 & $0.64(\mathrm{~T})$ & $0.81(\mathrm{~T})$ & $1.07(\mathrm{ST})$ & $0.89(\mathrm{~T})$ & 0.86 \\
\hline Average & $0.61 \mathrm{ab}$ & $0.77 \mathrm{a}$ & $1.28 \mathrm{a}$ & $0.84 \mathrm{a}$ & \\
\hline
\end{tabular}

Note: The numbers with marked by different letters on the same row and column show significant based on Duncan's multiple range test at $5 \%$ level.

Based on Duncan's test, it can be seen that there is no significant difference in $\mathrm{K}$ content between organic fertilizer treatment and mulch treatment. However, in observing the average soil $\mathrm{K}$ content, the highest treatment was in the B2 treatment (compost fertilizer) with a value of $1.28 \mathrm{me} / 100 \mathrm{~g}$ and the lowest was in B0 (without organic matter) with a value of $0.61 \mathrm{me} / 100 \mathrm{~g}$. In Table 9 it can also be seen that the highest treatment without $\mathrm{K}$ exchange mulch is in treatment B2 (sorghum plants and compost) which is $1.49 \mathrm{me} / 100 \mathrm{~g}$, the lowest in B0 (sorghum plants, without organic fertilizer) is $0.57 \mathrm{me} / 100 \mathrm{~g}$. Whereas in the treatment with the highest K-exchange mulch on B2 (sorghum and compost plants) that is $1.07 \mathrm{me} / 100 \mathrm{~g}$ and the lowest is on B0 (sorghum plants, without organic fertilizer) that is $0.64 \mathrm{me} / 100 \mathrm{~g}$. The condition of MOB0 is sorghum plants without mulch treatment and without organic fertilizer treatment, giving a value of $0.57 \mathrm{me} / 100 \mathrm{~g}$ means that sorghum plants can increase the $\mathrm{K}$ exchange value of land by $96.55 \%$ from the condition of natural / initial soil (K0) where the soil exchange rate $\mathrm{K}$ is $0.29 \mathrm{me} / 100 \mathrm{~g}$.

Cation exchange capacity (CEC) (me / 100g). For the CEC parameters, organic fertilizer treatment had a real effect, while mulch treatment, as well as combination treatment did not have a significant effect (Table 10). Based on Duncan's test, the mixture of cow manure treatment with compost (B3) is significantly different from the treatment of cow manure (B1) and compost (B2), there is a difference in the value of CEC between organic fertilizer treatments.

Table 10 - Effects of sorghum, mulch and organic matter cultivation on soil CEC (me/100g)

\begin{tabular}{|c|c|c|c|c|c|}
\hline Treatment & B0 & B1 & B2 & B3 & Average \\
\hline M0 & $20.58(\mathrm{~S})$ & $21.74(\mathrm{~S})$ & $22.71(\mathrm{~S})$ & $27.10(\mathrm{~T})$ & 23.03 \\
\hline M1 & $19.06(\mathrm{~S})$ & $20.06(\mathrm{~S})$ & $19.33(\mathrm{~S})$ & $25.77(\mathrm{~T})$ & 21.05 \\
\hline Average & $19.82 \mathrm{~d}$ & $20.90 \mathrm{c}$ & $21.02 \mathrm{~b}$ & $26.43 \mathrm{a}$ & \\
\hline
\end{tabular}

Note: The numbers with marked by different letters on the same row and column show significant based on Duncan's multiple range test at $5 \%$ level.

In Table 10 it can be seen that the highest CEC is in the B3 treatment (cow manure + compost) with a value of $26.43 \mathrm{me} / 100 \mathrm{~g}$ and the lowest is in B0 (without organic matter) with a value of 19.82 me / $100 \mathrm{~g}$, there is an increase in CEC by $33.35 \%$, and based on Duncan's distance test significantly different between organic fertilizer treatments.

In the treatment without mulch the highest soil CEC was found in the B3 treatment (sorghum plants, manure and compost) which was $27.10 \mathrm{me} / 100 \mathrm{~g}$ and the lowest was in B0 (sorghum plants, without organic fertilizer) which was $20.58 \mathrm{me} / 100 \mathrm{~g}$. Likewise in the 
treatment with CEC mulch the highest soil in B3 (sorghum plants, manure and compost) is $25.77 \mathrm{me} / 100 \mathrm{~g}$ and the lowest is in B0 (without organic fertilizer) which is $19.06 \mathrm{me} / 100 \mathrm{~g}$. The treatment of a mixture of cow manure with compost can increase the soil cation exchange capacity, because a mixture of cow manure and compost is an organic material that can affect the physical, chemical and biological nature of the soil, in this case increasing the value of the CEC to exchange the land value by $17.60 \%$ from the initial soil condition (K0) whose CEC is $17.50 \mathrm{me} / 100 \mathrm{~g}$.

\section{CONCLUSION}

Treatment of cow manure + compost (B3) can increase stem diameter by $35.21 \%$ when compared to treatment without organic fertilizer. Mulch treatment can increase the stem diameter by $5.06 \%$ when compared to the treatment without mulch. The highest sorghum production per plot was found in the compost organic fertilizer treatment, namely $4.25 \mathrm{~kg}$, an increase of $52.33 \%$ when compared to that without the organic fertilizer treatment, and an increase in production of $3.41 \%$ compared to the treatment of cow manure. In addition, cultivating sorghum either without mulching or by applying mulch and organic fertilizers can improve soil chemical properties in dry land.

\section{REFERENCES}

1. BPS. 2019. Aceh Besar in Figures 2019. Central Statistics Agency. Aceh Besar.

2. Bukhari \& Febryano, I.G. 2010. Agroforestry design in critical lands: A Case study in Indrapuri Sub-district, Aceh Besar Regency. Jurnal Perennial, 6(1): 53-59.

3. Datta, A., Mandal, B., Badole, S., Chaitanya, A.K., Majumder, S.P., Padhan, D., Basak, N., Barman, A., Kundu, R., \& Narkhede, W.N. 2018. Interrelationship of biomass yield, carbon input, aggregation, carbon pools and its sequestration in Vertisols under longterm sorghum-wheat cropping system in semi-arid tropics. Soil \& Tillage Research 184 (2018) 164-175. https://doi.org/10.1016/j.still.2018.07.004.

4. Erwin, 2007. Bahan organik untuk meningkatkan kualitas lahan and produksi tanaman tembakau deli (Nicotiana tabccum. L.). Desertasi. Program Doktor Ilmu Pertanian Universitas Sumatera Utara.

5. Hanafiah, A. S., T. Sabrina \& H. Guchi. 2009. Biologi and ekologi tanah. Fakultas Pertanian, Universitas Sumatera Utara, Medan.

6. Irawan, D.Z., Ezward, C., \& Okalia, D. 2020. The effect of buffalo manure and urea on the growth and production of sorghum (Sorghum bicolor (L.) Moench). Jurnal Green Swarnadwipa. 9(1): 46-57.

7. Irmansyah, T., Rauf, A., Delvian \& Akoeb, E.N. 2020. Soil characteristics of dry land in Indrapuri and Blang Bintang Sub-districts, Aceh Besar Regency, Aceh Province. RJOAS. 8(104): 57-62. DOI: 10.18551/rjoas.2020-08.07.

8. Mahyuddin, Sugianto \& Alvisyahrin, T. 2013. Forest land cover analysis of krueng aceh watershed in pre and post-tsunami. Jurnal Manajemen Sumberdaya Lahan 2(3): 296303.

9. Manonggotua, I., L. Mawarni \& T. Irmansyah. 2015. Respons pertumbuhan and produksi dua varietas sorgum (Sorghum bicolor (L.) Moench) terhadap mulsa organik di lahan sawah. Fakultas Pertanian. Universitas Sumatera Utara. Medan.

10. Marschner. H. 2012. Mineral nutrition oh higher plant. Academic Press, London.

11. Melati, M. \& W. Andriyani. 2005. Effect of chicken manure and green manure Calopogonium mucunoides on the growth and production of young harvested soybeans that are cultivated organically. Bul Agron. 33(2)8-15.

12. Nagur, Y. 2017. Kajian hubungan bahan organik tanah terhadap produktivitas lahan tanaman padi di Desa Kenonagung. Program Studi Agroteknologi Fakultas Pertanian Universitas Pembangunan Nasional Veteran Yogyakarta. 
13. Nasution, N.,Yusnaini, S., Niswati, A \& Dermiyati, 2015. Respirasi tanah pada sebagian lokasi di hutan Taman Nasional Bukit Barisan Selatan (TNBBS). J. Agrotek Tropika. 3(3): $427-433$.

14. Pramanda, R.P., Hidayat, K.F., Sunyoto, \& Kamal, M. 2015. Effect of application of organic materials on growth and yield of several sorghum varieties (Sorghum Bicolor [L] Moench). J. Agrotek. Tropika. 3(1):85-91

15. Prihastanti, E. 2010. Jatropha curcas L. nursery for different soil types and compost additions. Buletin Anatomi and Fisiologi. 18(2).

16. Sandrawati, A. 2007. Effect of municipal solid waste compost and chicken manure on soil chemical properties and yield of sweet corn (Zea Mays Saccharata) on Fluventic Eutrudeps from Jatinangor, Sumedang Regency. J. Ilmu Tanah. 14: 13-14.

17. Syahidah, A.M. \& Hermiyanto, B. 2019. Effect of cow manure and SP-36 fertilizer on improvement of soil chemical properties, growth and production of sorghum (sorghum bicolor) plants in soil contaminated with solid waste of paper mills (Lime mud). Berkala Ilmiah Pertanian. 2(3): 132-140.

18. Tacoh E, Rumambi A., \& Kaunang W. 2017. The effect of using wow bokashi fertilizer on the production of Kawali Variety Sorghum. Jurnal Zootek. 37(1): 88-95.

19. Tamba, H., T. Irmansyah, \& Hasanah, Y. 2016. Growth response and soybean production to the application of cow manure and liquid organic fertilizer. Jurnal Agroekoteknologi. 5 (40): 307- 314 307. [In Indonesian].

20. Wang, C., Zhou, L., Zhang, G., Xu, Y., Zhang, L., Gao, Xu, Gao, J., Jiang, Ne., \& Shao, M. 2017. Optimal fertilization for high yield and good quality of waxy sorghum (Sorghum bicolor L. Moench). Field Crops Research. 203(2017):1-7. http://dx.doi.org/10.1016/j.fcr.2016.12.009. 